\title{
BMJ Open Unsafe sexual behaviour in domestic and foreign migrant male workers in multinational workplaces in Jordan: occupational-based and behavioural assessment survey
}

\author{
Rami Al Rifai, ${ }^{1}$ Keiko Nakamura, ${ }^{1}$ Kaoruko Seino, ${ }^{1}$ Masashi Kizuki, ${ }^{2}$ Ayako Morita ${ }^{2}$
}

To cite: Al Rifai $\mathrm{R}$,

Nakamura K, Seino K, et al. Unsafe sexual behaviour in domestic and foreign migrant male workers in multinational workplaces in Jordan: occupational-based and behavioural assessment survey. BMJ Open 2015;5: e007703. doi:10.1136/ bmjopen-2015-007703

- Prepublication history for this paper is available online. To view these files please visit the journal online (http://dx.doi.org/10.1136/ bmjopen-2015-007703).

Received 16 January 2015 Revised 4 May 2015 Accepted 19 May 2015

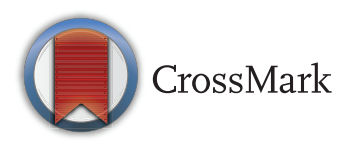

${ }^{1}$ Division of Public Health, Department of International Health and Medicine, Graduate School of Medical and Dental Sciences, Tokyo Medical and Dental University, Tokyo, Japan ${ }^{2}$ Division of Public Health, Department of Health Promotion, Graduate School of Medical and Dental Sciences, Tokyo Medical and Dental University, Tokyo, Japan

Correspondence to Dr Keiko Nakamura; nakamura.ith@tmd.ac.jp

\section{ABSTRACT}

Objectives: To examine the prevalence of unsafe sexual behaviour, sexually transmitted infection (STI)related knowledge, health and work-related conditions, and correlates of practising unsafe sex among domestic and foreign male workers in multinational workplaces in Jordan.

Design: Cross-sectional behavioural assessment survey.

Setting: Multinational workplaces in Jordan.

Participants: 230 Jordanian and 480 foreign male workers aged $\geq 18$ years who had worked in a Qualified Industrial Zone (QIZ) for 12 months or more.

Outcomes: The primary outcome was the prevalence of practising unsafe sex. 'Unsafe sex' was defined as sex with a non-regular sexual partner with inconsistent condom usage.

Results: Overall, $74.3 \%$ of workers reported lifetime sexual experience. The proportion of lifetime unsafe sex was similar among domestic (31.8\%) and foreign $(35.6 \%)$ workers. Of those, $59.2 \%$ of domestic and $68.1 \%$ of foreign workers started practising unsafe sex after joining the QIZ. Rates of lifetime unsafe sex were significantly higher among those who had their sexual debut after joining the QIZ in domestic (aOR, 2.2, $95 \% \mathrm{Cl} 1.1$ to 4.4 ) and foreign workers (aOR, $2.4,95 \% \mathrm{Cl} 1.4$ to 4.1 ). Among the domestic workers, being 18-24 years old (aOR, 4.9), unmarried (aOR, 4.8), working in the QIZ for 5-8 years (aOR, 5.0), sometimes/frequently shopped with foreign workers $(\mathrm{aOR}, 2.1)$ or were current/exalcohol drinkers (aORs, 3.4) were independently significantly associated with higher odds of practising unsafe sex.

Conclusions: A significant proportion of domestic and foreign male workers had been practising unsafe sex. The findings indicated that not only foreigners but also domestic male workers associating with foreign workers are at high risk of unsafe sex. Tailored interventions to promote safer sex in multinational workplaces in Jordan are needed.

\section{Strengths and limitations of this study}

- This study focused on examining the practice of unsafe sexual behaviour among domestic local male workers socialising with foreign migrant workers in multinational workplaces.

- The results suggest that not only foreigners, but also domestic male workers associating with foreign workers are at high risk of unsafe sex.

- The achieved high response rate was as a result of using well-trained, native-speaker interviewers, confidential interviews and maintaining good communication between employers and authorities throughout the research process.

- The reliability and validity of identifying workers with unsafe sexual behaviour were improved through anonymous interviews and through the use of structured questions to investigate unsafe sex practices.

- Behavioural data were collected from a crosssectional survey and the findings are based on self-reports; therefore, the collected data on personal socially sensitive behaviour may be subject to underestimation and social desirability bias.

\section{INTRODUCTION}

Migration and mobility facilitate high-risk sexual activities. Migration is often associated with family separation, acculturation and a greater sense of anonymity leading to unsafe behavioural changes such as early sexual debut. ${ }^{12-5}$ Early sex initiation and subsequent unsafe behaviours, such as sex with multiple sexual partners with inconsistent or non-use of condoms, further exacerbate the spread of sexually transmitted infections (STIs) ${ }^{6}{ }^{7}$ Few studies have discussed the risk of unsafe sexual behaviour and socialisation among domestic workers and migrants. ${ }^{8} 9$ Domestic workers who live and socialise with migrants in various settings should thus be 
carefully studied to elucidate their vulnerability to unsafe behaviours.

Over the past two decades, Jordanian society has experienced significant changes. Its total population has increased by $92 \% .{ }^{10}$ It is estimated that there are 3 million migrants of two types in Jordan: ${ }^{11}$ forced-process migrants, includingrefugees from Palestine, ${ }^{12}$ Iraq $^{13}$ and Syria $;{ }^{14}$ and free-process migrants, includingexpats in local markets and the Qualified Industrial Zones (QIZs). ${ }^{15}$ Average age at marriage has increased to 30 years among males. ${ }^{16}$ The cost of living index increased by $36 \%$ between 2006 and 2012. ${ }^{17}$ Mobile phone coverage is over $140 \%,{ }^{18}$ and nearly $57 \%$ of households have access to the internet. ${ }^{17}$ These changes, alongside the influx of multinational workers in QIZs, have raised public concern regarding engagement in unsafe sexual behaviours.

In Jordan, over $92 \%$ of the population is Muslim, ${ }^{19}$ where sex is only permissible within marriage. ${ }^{20}$ Among women aged 18-45 years, as a proxy for the general population, the prevalence of Chlamydia trachomatis infection was $0.6 \%$, Neisseria gonorrhoeae $2.2 \%$, syphilis $0.0 \%$ and Trichomonas vaginalis $0.5 \% .^{21}$ On the other hand, $72.3 \%$ of the 1022 confirmed HIV cases diagnosed between 1986 and 2013 were in non-Jordanians. ${ }^{22}$ Thus, despite the currently low STI prevalence estimates, the possibility of widespread STI epidemics developing in Jordan still persists.

In collaboration with the United States Agency for International Development (USAID) and Family Health International, the Ministry of Health of Jordan has implemented a workplace-based unsafe sexual behavioural prevention programme in QIZs and small businesses. According to its final report, $33 \%$ of sexually active Jordanian workers in QIZs and $21 \%$ in small businesses reported non-regular sexual $\operatorname{partner}(\mathrm{s}) .^{23}$ However, this study provided only descriptive estimates without further examining the factors associated with sexual behaviours.

We hypothesise that domestic workers (permanent residents of Jordan) and migrant foreign workers (non-permanent residents of Jordan), working with migrant workers of different nationalities, cultural and social backgrounds, have a great chance of coming in contact and socialising with each other. To date, however, there have been no epidemiological studies looking at the effects of domestic workers socialising with foreign workers in terms of unsafe sexual behaviours.

Solid evidence on behavioural changes among workers in QIZs is critical to the development of effective prevention programmes. The aims of our study, therefore, were to examine the proportion of unsafe sexual behaviour, STI-related knowledge, health and work-related conditions and correlates of practising unsafe sex among domestic and foreign male workers in multinational workplaces in Jordan.
METHODS

Setting

In the six multinational QIZs operating in Jordan, there are 28613 foreign and 8106 domestic Jordanian workers. ${ }^{15}$ Foreign workers, who represent approximately $78 \%$ of the total workers in the QIZs, are mainly from Bangladesh, India, Sri Lanka, Indonesia, Myanmar and the Philippines. From May to July 2012, we conducted a behavioural assessment survey in the Al-Hassan QIZ. This QIZ was established in 1991, and in 1998 was designated as the first QIZ in the world with a total of 14094 multinational employees working in 27 factories as recorded in 2011. Of them, 3806 (male: 35.7\%; female: $64.3 \%$ ) and 10288 (male: $44.9 \%$; female: $55.1 \%)$ are domestic and foreign workers, respectively. ${ }^{15}$

The study protocol was approved and conducted in accordance with the Jordan Ministry of Health's regional ethical standards committee (No. TT-3479). Written or witnessed informed consent was obtained from all participants.

\section{Sample size}

A minimum required sample size of 384 workers was calculated based on an unknown prevalence of unsafe sexual behaviour with a 5\% margin of error and $95 \%$ CI. With the application of an expected $85 \%$ participation rate, and the need to adjust for potential confounders, it was determined that an effective minimum sample size of 440 respondents was required for this survey. However, to have more robust estimates, the final sample size was determined to be at least 600 workers. We therefore aimed to approach 710 male workers to recruit at least 600 participants considering a $15 \%$ drop rate.

\section{Subjects}

The subjects were selected using stratified multistage random sampling among male workers aged $\geq 18$ years who had worked in the QIZ for 12 months or more. The sampling frame was a list of all male employees except general managers/directors in the 27 factories that was obtained from the factories' administrations. First, 11 factories were selected with a probability proportional to the number of workers. Then, from 1377 domestic and 2932 foreign eligible male workers in the 11 factories, 230 domestic and 480 foreign male workers were randomly selected. Stratified selection was implemented to reflect the proportion of workers in the sampling frame according to residential status (domestic, foreigner). Selected male foreign workers were of Bangladeshi, Indian and Sri Lankan nationalities. These four nationalities were representing more than $70 \%$ of the male foreign workers in the QIZ. A majority $(96 \%)$ of the workers listed in the sampling frame were tailors or porters. Female employees were excluded from this study due to an expected high non-response rate particularly among domestic Muslim females given the 
cultural barriers and fear of being discriminated against in the working place or the society, as had been evaluated in a small pilot study.

Out of the 710 randomly selected workers, 662 $(93.2 \%)$ were approached; the other $48(6.8 \%)$ had already resigned at the time of the field survey. Among the 662 interviewed workers, 619 (response rate: 92.1\%) consented to participate. Of the 43 (2 domestic and 41 foreign workers) who refused to participate in the study, the highest non-response rate was from Sri Lankan $(22.3 \%)$ followed by Indian workers (12\%). The response 'none' was mainly due to absence at the time of the survey or a fear of being identified and unwillingness to discuss personal information.

\section{Procedures}

The survey team conducted face-to-face anonymous interviews using a standardised questionnaire. The structured questionnaire was developed in English and translated into the Arabic, Bangla, Hindi and Sinhala languages by native speakers. Back-translations were rechecked for conformity by native-speaker reviewers. Workers received full explanation about the nature of the study and voluntary participation.

The survey team consisted of five native interviewers (two Arabic speakers, and one each of Bangla, Hindi and Sinhala native speakers). Research team members received five days of training to become conversant with the survey procedures. The quality of the data collection was standardised using repeated pretests.

\section{Outcome}

The measurement of our outcome of interest, the practice of unsafe sex, was based on composite indicators. 'Regular partner' was defined as an officially married wife or sole live-in sexual partner, while 'Non-regular partner' included commercial or casual sexual partners. ${ }^{24}$ Frequency of condom usage was also assessed. 'Unsafe sex' was defined as sexual intercourse with a non-regular sexual partner(s) without using condoms consistently.

\section{Predictors}

Sociodemographics

Age was classified as $18-24,25-29$ or $\geq 30$ years. Religion was reported in two categories (Muslims and non-Muslims). The monthly minimum wage in Jordan is 190 Jordanian dinars (JDs) for Jordanians (equivalent to \$US 268) and 150JDs for foreign workers (equivalent to \$US 211). ${ }^{25}$ Taking into consideration that this minimum wage is in addition to the incentives the workers receive based on the number of garment pieces they produce per day, the monthly income was arbitrarily divided into three categories $(<200,200-300$ or $>300 \mathrm{JDs})$. Education was categorised as elementary and below, secondary or senior secondary and college. Marital status was classified as married living with wife, married living away from wife or unmarried. Length of time of having worked at the QIZ was categorised into four groups ( $1-\leq 4,5-8$ or $\geq 9$ years).

\section{Health-related and working conditions}

Total hours of sleep per day were reported in three groups $(\leq 6,7-8$ or $\geq 9 \mathrm{~h}$ ). Self-perceived health status was categorised into three groups (fair/poor, good/very good or excellent). With regard to tobacco smoking (current smoker, ex-smoker or never-smoker) and alcohol intake (current drinker, ex-drinker or neverdrinker), each item was categorised into three groups. Counts of working days per week ( 5 or $>5$ days), working hours per day $(\leq 8$ or $>8 \mathrm{~h})$ and working after 21:00 (never, sometimes or everyday) were reported.

\section{Socialisation with domestic/foreign workers}

We measured socialisation by assessing the personal contact with foreign workers of different nationalities. We formulated specific questions as a proxy for socialisation that assessed the frequency of sharing daily meals and shopping together with foreign/domestic male or female workers. In a high loaded working environment, shopping together or sharing daily meals are the major activities whereby workers could get to know, interact and socialise with each other. The response to each item was reported as 'never', 'sometimes' or 'frequently'.

\section{STI-related knowledge}

Workers were asked whether they had heard the term 'sexually transmitted infections' (yes or no). Knowledge of HIV transmission was measured using 14 yes/no items. These two variables have been validated previously. ${ }^{26}$ Further validation was performed by validating and piloting the translated questionnaire before conducting the actual survey. For the items measuring knowledge of HIV transmission, correct answers were scored as ' 1 ' and incorrect answers were scored as ' 0 '. The total score ranging from 0 to 14 was subcategorised into two categories (0-7 or 8-14). Knowledge about the role of condoms in protection against STIs/AIDS was evaluated using a three-level variable (yes, no or never heard of condoms). According to the number of STIs/ AIDS workshops that they had attended, the subjects were categorised into two groups (never or attended at least one workshop).

\section{Sexual experience and behaviour}

Workers were categorised into two groups based on sexual exposure (never or ever), age at first sex ( $\leq 24$ or $\geq 25$ years) and sexual debut in relation to joining the QIZ (before or after). Workers with lifetime sexual experience were categorised into two groups of 'ever' or 'never had unsafe sex', for the debut of unsafe sex in relation to joining the QIZ (before or after), and for the gender of the sexual partner(s) (homosexual or heterosexual). All sexually active workers since joining the QIZ were classified into three groups based on their types of sexual partner(s) (only regular partner, only non-regular partner 
Table 1 Sociodemographics, health-related characteristics, working conditions and socialisation activities by residential status

\begin{tabular}{|c|c|c|c|c|c|}
\hline & \multicolumn{5}{|c|}{ Residential status } \\
\hline & \multicolumn{2}{|c|}{$\begin{array}{l}\text { Domestic } \\
\mathrm{N}=223\end{array}$} & \multicolumn{2}{|c|}{$\begin{array}{l}\text { Foreigner } \\
\mathrm{N}=396\end{array}$} & \multirow[b]{2}{*}{ p Value } \\
\hline & $\overline{\mathbf{n}}$ & Per cent & $\overline{\mathbf{n}}$ & Per cent & \\
\hline \multicolumn{6}{|l|}{ Sociodemographics } \\
\hline Age (years) & & & & & $<0.001$ \\
\hline$\geq 30$ & 107 & 48.0 & 189 & 47.7 & \\
\hline $25-29$ & 50 & 22.4 & 159 & 40.2 & \\
\hline $18-24$ & 66 & 29.6 & 48 & 12.1 & \\
\hline Religion & & & & & $<0.001$ \\
\hline Muslim & 222 & 99.5 & 238 & 60.1 & \\
\hline Non-Muslim* & 1 & 0.5 & 158 & 39.9 & \\
\hline Monthly income (Jordanian Dinars) & & & & & $<0.001$ \\
\hline$<200$ & 99 & 44.4 & 271 & 68.4 & \\
\hline $200-300$ & 80 & 35.9 & 99 & 25.0 & \\
\hline$>300$ & 44 & 19.7 & 26 & 6.6 & \\
\hline Education & & & & & $<0.001$ \\
\hline Elementary and below & 9 & 4.0 & 78 & 19.7 & \\
\hline Secondary & 50 & 22.4 & 148 & 37.4 & \\
\hline Senior secondary and college & 164 & 73.5 & 170 & 42.9 & \\
\hline Marital status & & & & & $<0.001$ \\
\hline Married, living with wife & 101 & 45.3 & 65 & 16.4 & \\
\hline Married, living away from wife & 4 & 1.8 & 156 & 39.4 & \\
\hline Unmarried & 118 & 52.9 & 175 & 44.2 & \\
\hline Total years of work at QIZ & & & & & $<0.001$ \\
\hline $1-\leq 4$ & 86 & 38.6 & 213 & 53.8 & \\
\hline $5-8$ & 70 & 31.4 & 163 & 41.2 & \\
\hline$\geq 9$ & 67 & 30.0 & 20 & 5.1 & \\
\hline \multicolumn{6}{|l|}{ Health-related characteristics } \\
\hline Total hours of sleep per day & 100 & 44.8 & 125 & 31.6 & $<0.001$ \\
\hline$\leq 6$ & 94 & 42.2 & 235 & 235 & \\
\hline$\overline{7}-8$ & 29 & 13.0 & 36 & 36 & \\
\hline$\geq 9$ & & & & & \\
\hline Self-perceived health status & & & & & $<0.001$ \\
\hline Fair/poor & 14 & 6.3 & 120 & 30.3 & \\
\hline Good/very good & 153 & 68.6 & 115 & 29.0 & \\
\hline Excellent & 56 & 25.1 & 158 & 39.9 & \\
\hline Missing & & & 3 & & $<0.001$ \\
\hline \multicolumn{6}{|l|}{ Smoking } \\
\hline Smoker & 132 & 59.2 & 175 & 44.2 & \\
\hline Ex-smoker & 14 & 6.3 & 10 & 2.5 & \\
\hline Never & 77 & 34.5 & 211 & 53.3 & \\
\hline Alcohol intake & & & & & $<0.001$ \\
\hline Drinker & 22 & 9.9 & 155 & 39.1 & \\
\hline Ex-drinker & 35 & 15.7 & 0 & 0.0 & \\
\hline Never & 166 & 74.4 & 241 & 60.9 & \\
\hline \multicolumn{6}{|l|}{ Working conditions } \\
\hline Weekly working days & & & & & $<0.001$ \\
\hline 5 & 19 & 8.5 & 0 & 0.0 & \\
\hline$>5$ & 204 & 91.5 & 396 & 100.0 & \\
\hline Daily working hours & & & & & $<0.001$ \\
\hline$\leq 8$ & 142 & 63.7 & 39 & 9.8 & \\
\hline$>8$ & 81 & 36.3 & 357 & 90.2 & \\
\hline Working after 21:00 & & & & & 0.134 \\
\hline Never & 172 & 77.1 & 293 & 74.0 & \\
\hline Sometimes & 41 & 18.4 & 68 & 17.2 & \\
\hline Everyday & 10 & 4.5 & 35 & 8.8 & \\
\hline
\end{tabular}


Table 1 Continued

\begin{tabular}{|c|c|c|c|c|c|}
\hline & \multicolumn{5}{|c|}{ Residential status } \\
\hline & \multicolumn{2}{|c|}{$\begin{array}{l}\text { Domestic } \\
\mathrm{N}=223\end{array}$} & \multicolumn{2}{|c|}{$\begin{array}{l}\text { Foreigner } \\
\mathrm{N}=396\end{array}$} & \multirow[b]{2}{*}{ p Value } \\
\hline & $\overline{\mathbf{n}}$ & Per cent & $\bar{n}$ & Per cent & \\
\hline \multicolumn{6}{|l|}{ Socialisation activities } \\
\hline \multicolumn{5}{|l|}{ Sharing meals with foreign workers $\ddagger$} & $<0.001$ \\
\hline Never & 173 & 77.6 & 348 & 87.9 & \\
\hline Sometimes & 32 & 14.3 & 42 & 10.6 & \\
\hline Frequently & 18 & 8.1 & 6 & 1.5 & \\
\hline \multicolumn{5}{|l|}{ Shopping together with foreign workersł } & $<0.001$ \\
\hline Never & 158 & 70.9 & 347 & 87.6 & \\
\hline Sometimes & 33 & 14.8 & 41 & 10.4 & \\
\hline Frequently & 32 & 14.3 & 8 & 2.0 & \\
\hline \multicolumn{5}{|l|}{ Sharing meals with domestic workers } & $<0.001$ \\
\hline Never & 25 & 11.2 & 327 & 82.6 & \\
\hline Sometimes & 27 & 12.1 & 59 & 14.9 & \\
\hline Frequently & 171 & 76.7 & 10 & 2.5 & \\
\hline \multicolumn{5}{|l|}{ Shopping together with domestic workers } & $<0.001$ \\
\hline Never & 30 & 13.5 & 370 & 93.4 & \\
\hline Sometimes & 62 & 27.8 & 22 & 5.6 & \\
\hline Frequently & 131 & 58.7 & 4 & 1.0 & \\
\hline \multicolumn{6}{|c|}{$\begin{array}{l}\text { p Values are derived from } \chi^{2} \text { tests of cross-tabulation between residential status and each category. } \\
{ }^{\star} \text { Non-Muslims include Christians, Hindus and Buddhists. } \\
\text { †Includes widowed and divorced. } \\
\text { fEither with male or female workers, except those of the same nationality. }\end{array}$} \\
\hline
\end{tabular}

(s), or regular and non-regular partners). Workers who reported unsafe sex were further classified into three groups according to their residential status (domestic, foreigner or both domestic and foreign) and the source of their unsafe sexual partner (from within the QIZ, from outside the QIZ or from within and outside the QIZ).

\section{Condom usage and practices}

Sexually active workers were categorised into three groups based on their frequency of condom usage in the prior 12 months (never, sometimes or every time) including in the last sexual intercourse, with further classification based on their frequency of condom usage (never, sometimes or every time) according to the type of sexual partner(s): with only regular partner(s), with only non-regular partner(s) and with both regular and non-regular partners.

\section{Statistical analysis}

Frequency distribution and percentages were generated for each measured variable. Bivariate analyses were performed to explore the potential differences in the measured variables between domestic and foreign workers using $\chi^{2}$ tests. The crude and adjusted association of the measured variables with practice of unsafe sex was assessed by running logistic regression models separately for domestic and foreign workers. To investigate the impact of lifetime sexual debut in relation to joining the QIZ and the workers' ages at first sex on the outcome variable, additional logistic regression models were run separately for domestic and foreign workers. Adjusting for potential confounders was performed by entering sociodemographic, STI-related knowledge, smoking and alcohol intake variables simultaneously into a logistic regression model. To assess the effect of socialisation on the outcome variable, we compared the odds of practising unsafe sex among workers who frequently/sometimes shared meals or went shopping together with those of other workers who never did so, for both domestic and foreign workers, separately. The adjusted ORs (aORs) and 95\% CIs were reported to determine the magnitude and direction of the associations. Analyses were performed using SPSS V.18.0 (IBM, Armonk, New York, USA). Statistical significance was set at a two-sided $\mathrm{p}$ value $\leq 0.05$.

\section{RESULTS}

\section{Study participants}

Of the selected 230 domestic and 480 foreign male workers (184 Bangladeshis, 143 Indians and 153 Sri Lankans), $223(97 \%)$ and $396(82.5 \%)$ responded to the questionnaire respectively. Table 1 shows the rest of the sociodemographic and health-related characteristics, working conditions and socialisation characteristics of the 619 interviewed workers according to residential status.

\section{STI-related knowledge and sexual experience and behaviours}

Table 2 shows the workers' STI-related knowledge and sexual experience and behaviour by residential status. 
Table 2 STI-related knowledge and sexual experience and behaviours according to residential status

\begin{tabular}{|c|c|c|c|c|c|}
\hline & \multicolumn{5}{|c|}{ Residential status } \\
\hline & \multicolumn{2}{|c|}{ Domestic } & \multicolumn{2}{|c|}{ Foreigner } & \multirow[b]{2}{*}{ p Value } \\
\hline & n & Per cent & $\overline{\mathbf{n}}$ & Per cent & \\
\hline \multicolumn{6}{|l|}{ STI-related knowledge } \\
\hline Heard of the term STIs & & & & & 0.001 \\
\hline Yes & 173 & 77.6 & 257 & 64.9 & \\
\hline No & 50 & 22.4 & 139 & 35.1 & \\
\hline HIV/AIDS knowledge, total score & & & & & 0.001 \\
\hline $0-7$ & 59 & 26.5 & 62 & 15.7 & \\
\hline $8-14$ & 164 & 73.5 & 334 & 84.3 & \\
\hline Condoms can protect against STIs/AIDS & & & & & $<0.001$ \\
\hline Yes & 97 & 43.5 & 314 & 79.3 & \\
\hline No & 105 & 47.1 & 66 & 16.7 & \\
\hline Never heard of condoms & 21 & 9.4 & 16 & 4.0 & \\
\hline Workshops on STIs/AIDS & & & & & $<0.001$ \\
\hline None & 201 & 90.1 & 298 & 75.3 & \\
\hline$\geq$ One & 22 & 9.9 & 98 & 24.7 & \\
\hline \multicolumn{6}{|l|}{ Sexual experience and behaviour } \\
\hline Ever had sex & & & & & 0.476 \\
\hline Never & 61 & 27.4 & 98 & 24.7 & \\
\hline Ever & 162 & 72.6 & 298 & 75.3 & \\
\hline Age at first sexual exposure, years (N: domestic=162; foreigner=298) & & & & & 0.227 \\
\hline$\leq 24$ & 94 & 58.0 & 190 & 63.8 & \\
\hline$\geq 25$ & 68 & 42.0 & 108 & 36.2 & \\
\hline Gender of the sexual partner(s) (N: domestic=162; foreigner=298) & & & & & 0.024 \\
\hline Heterosexual & 155 & 95.7 & 267 & 88.6 & \\
\hline Homosexual & 7 & 4.3 & 31 & 10.4 & \\
\hline Sexual debut in relation to work at $\mathrm{QIZ}$ (N: domestic=162; foreigner=298) & & & & & 0.287 \\
\hline Before joining QIZ & 89 & 54.9 & 179 & 60.1 & \\
\hline After joining QIZ & 73 & 45.1 & 119 & 39.9 & \\
\hline Ever had unsafe sexual partner(s) (N: domestic=162; foreigner=298) & & & & & 0.473 \\
\hline Never & 91 & 56.2 & 157 & 52.7 & \\
\hline Ever & 71 & 43.8 & 141 & 47.3 & \\
\hline $\begin{array}{l}\text { Unsafe, sexual debut in relation to work at QIZ (N: domestic=71; } \\
\text { foreigner=141) }\end{array}$ & & & & & 0.198 \\
\hline Before joining QIZ & 29 & 40.8 & 45 & 31.9 & \\
\hline After joining QIZ & 42 & 59.2 & 96 & 68.1 & \\
\hline $\begin{array}{l}\text { Type of sexual partner(s) since joining QIZ (N: domestic=162; } \\
\text { foreigner=298) }\end{array}$ & & & & & 0.161 \\
\hline Only regular partner & 91 & 56.2 & 157 & 52.7 & \\
\hline Only non-regular partner(s) & 54 & 33.3 & 108 & 36.2 & \\
\hline Regular and non-regular partner(s) & 9 & 5.6 & 33 & 11.1 & \\
\hline Missing (reported no sex)* & 8 & 4.9 & - & - & \\
\hline $\begin{array}{l}\text { Residential status of the unsafe partner since joining } \mathrm{QIZ}(\mathrm{N} \text { : domestic=63; } \\
\text { foreigner=141) }\end{array}$ & & & & & $<0.001$ \\
\hline Domestic & 10 & 15.6 & 2 & 1.4 & \\
\hline Foreigner & 46 & 73.0 & 134 & 95.0 & \\
\hline Both domestic and foreigner & 7 & 11.1 & 5 & 3.5 & \\
\hline $\begin{array}{l}\text { Source of the unsafe partner since joining QIZ (N: domestic=63; } \\
\text { foreigner=141) }\end{array}$ & & & & & 0.271 \\
\hline From within the QIZ & 30 & 47.6 & 54 & 38.3 & \\
\hline From outside the QIZ & 12 & 19.0 & 41 & 29.1 & \\
\hline From both within/outside the QIZ & 21 & 33.3 & 46 & 32.6 & \\
\hline
\end{tabular}

Compared to domestic workers, the percentage of foreign workers who reported that 'condoms can protect against STIs' was significantly higher. Among domestic and foreign workers, $90.1 \%$ and $75.3 \%$ of them never attended any workshop on STIs/AIDS. Regarding sexual experiences, the proportion of lifetime unsafe sex was 
similar among domestic (31.8\%) and foreign (35.6\%) workers. Among those who reported sexual experience, homosexuality was higher among migrant $(10.4 \%)$ than among domestic workers $(4.3 \% ; \mathrm{p}=0.024)$. Nearly $44 \%$ of the domestic and $47.3 \%$ of the foreign workers reported having had unsafe sex. The rate of unsafe sex was higher among homosexual foreign (80.6\%) and homosexual domestic $(85.1 \%)$ workers than that among heterosexual foreign (43.4\%) and heterosexual domestic (41.9\%) workers. For $59.2 \%$ of the domestic workers who reported lifetime unsafe sex, their unsafe sexual debut started after joining the QIZ. Among those who reported unsafe sex since joining the QIZ, $84 \%$ practised unsafe sex with foreign partner(s), and $80.9 \%$ of them had come in contact with their unsafe partners from within the QIZ.

\section{Condom usage and practices}

In the prior 12 months, sexually active domestic workers were more likely not to use condoms compared to foreign workers. Out of the 63 domestic workers who reported non-regular sexual partner(s) in the past 12 months, $88.9 \%$ had never used condoms. This percentage is significantly higher than that $(67.4 \%)$ among the 141 foreign workers who also reported non-regular partner(s) during the same period $(\mathrm{p}<0.02$; table 3$)$.

\section{Multivariate analysis on unsafe sex}

Table 4 shows the association of the measured covariates with unsafe sex after controlling for the influence of the measured covariates. Workers' age was significantly related to unsafe sex among domestic but not among foreign workers. The aORs on practising unsafe sex was $390 \%$ greater for workers aged 18-24 years compared to workers aged $\geq 30$ years. Marital status was also related to unsafe sex: compared to workers who were married and living with their spouses at the time of the survey, unmarried domestic and foreign workers were at $380 \%$ and $650 \%$ greater risk of practising unsafe sex, respectively. Domestic and foreign workers who used to frequently/sometimes shop together with other foreign workers were at $110 \%$ and $100 \%$ higher odds of unsafe sex, respectively. Domestic workers who were current or ex-alcohol drinkers demonstrated higher odds of practising unsafe sex.

Domestic workers with lifetime sexual debut after joining the QIZ or who had first sex at the age of $\leq 24$ years were at $120 \%$ and $520 \%$ greater risk of engaging in unsafe sex, respectively (table 5 ).

\section{DISCUSSION}

This study revealed a high prevalence of unsafe sex among workers at multinational workplaces in Jordan. Over one-third of workers reported having unsafe sex; two-thirds of them had started their unsafe sexual activities after joining the QIZ. The rate of unsafe sex was higher among domestic workers who started sexual activity after joining the QIZ, who had sexual partner(s) from within the QIZ, who had foreign sexual partner(s), or who socialised frequently/sometimes with foreign workers.

The present survey achieved a high response rate and improved the reliability and validity of results through the use of well-trained, native-speaker interviewers, standardised questionnaires, confidential interviews and maintaining good communication between employers and authorities throughout the research process. The reliability and validity of identifying workers with unsafe sexual behaviour were improved through anonymous interviews and through the use of structured questions to investigate unsafe sex practices.

\begin{tabular}{|c|c|c|c|c|c|}
\hline & \multicolumn{5}{|c|}{ Residential status } \\
\hline & \multicolumn{2}{|c|}{ Domestic } & \multicolumn{2}{|c|}{ Foreigner } & \multirow[b]{2}{*}{ p Value } \\
\hline & $\mathbf{n}$ & Per cent & $\mathbf{n}$ & Per cent & \\
\hline Condom usage (domestic $=154$; foreigner $=298$ ) & & & & & $<0.001$ \\
\hline Never & 124 & 80.5 & 177 & 59.4 & \\
\hline Sometimes & 19 & 12.3 & 90 & 30.2 & \\
\hline Every time & 11 & 7.1 & 31 & 10.4 & \\
\hline Used with only regular partner (domestic $=91$; foreigner $=157$ ) & & & & & 0.002 \\
\hline Never & 68 & 74.7 & 82 & 52.2 & \\
\hline Sometimes & 12 & 13.2 & 44 & 28.0 & \\
\hline Every time & 11 & 12.1 & 31 & 19.7 & \\
\hline Used with only non-regular partner(s) $($ domestic $=54$; foreigner $=108)$ & & & & & 0.029 \\
\hline Never & 48 & 88.9 & 80 & 74.1 & \\
\hline Sometimes & 6 & 11.1 & 28 & 25.9 & \\
\hline Every time & - & - & - & - & \\
\hline Used with regular and non-regular partner(s) (domestic=9; foreigner=33) & & & & & 0.020 \\
\hline Never & 8 & 88.9 & 15 & 45.5 & \\
\hline Sometimes & 1 & 11.1 & 18 & 54.5 & \\
\hline Every time & - & - & - & - & \\
\hline
\end{tabular}


Table 4 Crude and adjusted sociodemographic, HIV/STIs-related knowledge, socialisation and smoking, and alcohol intake determinants associated with practising unsafe sex by residential status and among all subjects

\begin{tabular}{|c|c|c|c|c|c|c|}
\hline & \multicolumn{4}{|l|}{ Residential status } & & \\
\hline & \multicolumn{2}{|l|}{ Domestic } & \multicolumn{2}{|l|}{ Foreigner } & \multicolumn{2}{|l|}{ All workers } \\
\hline & OR (95\% Cl) & aOR (95\% Cl) & OR (95\% Cl) & aOR (95\% Cl) & OR (95\% Cl) & aOR† (95\% Cl) \\
\hline \multicolumn{7}{|l|}{ Sociodemographics } \\
\hline \multicolumn{7}{|l|}{ Age, years } \\
\hline$\geq 30$ & 1.0 & 1.0 & 1.0 & 1.0 & 1.0 & 1.0 \\
\hline $25-29$ & $3.8(1.8 \text { to } 8.2)^{\star \star}$ & $1.9(0.6$ to 6.3$)$ & $1.3(0.8$ to 1.9$)$ & $0.9(0.4$ to 2.3$)$ & $1.8(1.2 \text { to } 2.6)^{\star \star}$ & $1.2(0.7$ to 1.9$)$ \\
\hline $18-24$ & $5.3(2.6 \text { to } 10.7)^{\star \star \star}$ & $4.9(1.3 \text { to } 18.2)^{\star}$ & $1.2(0.6$ to 2.4$)$ & $1.0(0.6$ to 1.8$)$ & $2.2(1.4 \text { to } 3.5)^{\star *}$ & 1.5 (0.8 to 2.9$)$ \\
\hline \multicolumn{7}{|l|}{ Monthly income (JDs) } \\
\hline$<200$ & 1.0 & 1.0 & 1.0 & 1.0 & 1.0 & 1.0 \\
\hline $200-300$ & $1.4(0.8$ to 2.7$)$ & $1.5(0.7$ to 3.3$)$ & $0.9(0.6$ to 1.5$)$ & $1.0(0.6$ to 1.8$)$ & $1.1(0.7$ to 1.5$)$ & $1.0(0.7$ to 1.6$)$ \\
\hline$>300$ & $0.9(0.4$ to 2.0$)$ & $1.4(0.5$ to 4.5$)$ & $0.8(0.3$ to 1.8$)$ & $0.8(0.3$ to 2.1$)$ & $0.8(0.4$ to 1.3$)$ & 1.0 (0.5 to 2.0$)$ \\
\hline \multicolumn{7}{|l|}{ Education } \\
\hline Senior secondary and college & 1.0 & 1.0 & 1.0 & 1.0 & 1.0 & 1.0 \\
\hline Secondary & $0.9(0.5$ to 1.9$)$ & 0.8 (0.3 to 1.9$)$ & $1.5(0.9$ to 2.4$)$ & $0.9(0.5$ to 1.8$)$ & $1.4(0.9$ to 1.9$)$ & $1.2(0.8$ to 1.8$)$ \\
\hline Elementary and below & $0.6(0.1$ to 2.9$)$ & $1.9(0.3$ to 11.5$)$ & $1.1(0.6$ to 2.4$)$ & $1.5(0.9$ to 2.5$)$ & $1.0(0.6$ to 1.7$)$ & $0.9(0.5$ to 1.7$)$ \\
\hline \multicolumn{7}{|l|}{ Marital status } \\
\hline Married, living with wife & 1.0 & 1.0 & 1.0 & 1.0 & 1.0 & 1.0 \\
\hline Married, living away from wife§ & $2.3(0.2$ to 23.3$)$ & 2.5 (0.2 to 34.2$)$ & $6.6(2.7 \text { to } 16.1)^{\star \star \star}$ & $6.9(2.7 \text { to } 17.1)^{\star \star \star}$ & $5.1(2.9 \text { to } 9.0)^{\star \star \star}$ & $5.9(3.1 \text { to } 11.0)^{\star \star \star}$ \\
\hline Unmarried & $6.3(3.2 \text { to } 12.6)^{\star \star \star}$ & $4.8(1.7 \text { to } 13.7)^{\star \star}$ & $7.0(2.9 \text { to } 17.1)^{\star \star \star}$ & $7.5(2.9 \text { to } 19.4)^{\star \star \star}$ & $6.2(3.6 \text { to } 10.5)^{\star \star \star}$ & $5.8(3.0 \text { to } 11.0)^{\star \star \star}$ \\
\hline \multicolumn{7}{|l|}{ Total years of work at QIZ } \\
\hline $1-\leq 4$ & 1.0 & 1.0 & 1.0 & 1.0 & 1.0 & 1.0 \\
\hline $5-\overline{8}$ & $2.1(1.1 \text { to } 4.0)^{\star}$ & $5.0(1.9 \text { to } 13.0)^{\star \star}$ & $1.3(0.8$ to 1.9$)$ & $1.3(0.7$ to 2.4$)$ & $1.5(1.0 \text { to } 2.1)^{\star}$ & $2.1(1.3 \text { to } 3.4)^{\star \star}$ \\
\hline$\geq 9$ & $0.8(0.4$ to 1.7$)$ & $6.0(1.7 \text { to } 20.8)^{\star \star}$ & $0.3(0.1$ to 1.2$)$ & $0.4(0.1$ to 1.5$)$ & $0.6(0.3$ to 1.0$)$ & $1.6(0.8$ to 3.5$)$ \\
\hline \multicolumn{7}{|l|}{ HIV/STIs-related knowledge } \\
\hline \multicolumn{7}{|l|}{ Heard of the term STIs } \\
\hline Yes & 1.0 & 1.0 & 1.0 & 1.0 & 1.0 & 1.0 \\
\hline No & $1.0(0.5$ to 1.9$)$ & $1.0(0.4$ to 2.2$)$ & $1.1(0.7$ to 1.6$)$ & $0.9(0.4$ to 1.9$)$ & $1.1(0.8$ to 1.5$)$ & $0.9(0.5$ to 1.4$)$ \\
\hline \multicolumn{7}{|l|}{ HIV/AIDS knowledge, score } \\
\hline $8-14$ & 1.0 & 1.0 & 1.0 & 1.0 & 1.0 & 1.0 \\
\hline $0-7$ & $2.1(1.1 \text { to } 3.8)^{\star \star \star}$ & $1.8(0.8$ to 3.8$)$ & $0.9(0.5$ to 1.6$)$ & $0.8(0.5$ to 1.6$)$ & $1.3(0.9$ to 1.9$)$ & $1.3(0.8$ to 2.0$)$ \\
\hline \multicolumn{7}{|c|}{ Condoms can protect against STIs/AIDS } \\
\hline Yes & 1.0 & 1.0 & 1.0 & 1.0 & 1.0 & 1.0 \\
\hline No/never heard of condoms & $1.8(1.0 \text { to } 3.1)^{\star \star \star}$ & $1.6(0.8$ to 3.2$)$ & $1.1(0.6$ to 1.8$)$ & $1.3(0.8$ to 2.4$)$ & $1.4(0.9$ to 2.1$)$ & 1.3 (0.9 to 2.0$)$ \\
\hline \multicolumn{7}{|l|}{ Workshops on STIs/AIDS } \\
\hline$\geq$ One & 1.0 & 1.0 & 1.0 & 1.0 & 1.0 & 1.0 \\
\hline None & $0.8(0.3$ to 2.0$)$ & $0.4(0.1$ to 1.2$)$ & $0.9(0.6$ to 1.4$)$ & $1.1(0.6$ to 1.8$)$ & $0.8(0.6$ to 1.3$)$ & $0.9(0.6$ to 1.5$)$ \\
\hline \multicolumn{7}{|l|}{ Socialisation } \\
\hline \multicolumn{7}{|l|}{ Sharing meals with foreign workers§ } \\
\hline Never & 1.0 & 1.0 & 1.0 & 1.0 & 1.0 & 1.0 \\
\hline Sometimes/frequently & $1.1(0.6$ to 2.2$)$ & $0.6(0.3$ to 1.5$)$ & $1.0(0.5$ to 1.9$)$ & $1.1(0.6$ to 2.2$)$ & $1.0(0.7$ to 1.6$)$ & $0.9(0.6$ to 1.5$)$ \\
\hline
\end{tabular}




\begin{tabular}{|c|c|c|c|c|c|c|}
\hline & \multicolumn{4}{|l|}{ Residential status } & \multirow{2}{*}{\multicolumn{2}{|c|}{ All workers }} \\
\hline & \multicolumn{2}{|l|}{ Domestic } & \multicolumn{2}{|l|}{ Foreigner } & & \\
\hline & OR (95\% Cl) & aOR (95\% Cl) & OR (95\% Cl) & aOR (95\% Cl) & OR (95\% Cl) & aOR† (95\% Cl) \\
\hline \multicolumn{7}{|c|}{ Shopping together with foreign workers $\uparrow$} \\
\hline Never & 1.0 & 1.0 & 1.0 & 1.0 & 1.0 & 1.0 \\
\hline Sometimes/Frequently & $2.0(1.1 \text { to } 3.7)^{\star \star *}$ & $2.1(1.0 \text { to } 4.3)^{\star}$ & $1.9(1.1 \text { to } 3.6)^{\star \star \star}$ & $2.0(1.1 \text { to } 4.0)^{\star \star \star}$ & $1.9(1.2 \text { to } 2.8)^{\star \star}$ & $1.8(1.1 \text { to } 2.9)^{\star \star \star}$ \\
\hline \multicolumn{7}{|c|}{ Sharing meals with domestic workers } \\
\hline Never & 1.0 & 1.0 & 1.0 & 1.0 & 1.0 & 1.0 \\
\hline Sometimes/frequently & $1.5(0.6$ to 4.1$)$ & $1.2(0.4$ to 3.6$)$ & $1.4(0.8$ to 2.4$)$ & $1.4(0.8$ to 2.7$)$ & $1.6(0.9$ to 3.0$)$ & 1.5 (0.9 to 2.6$)$ \\
\hline \multicolumn{7}{|c|}{ Shopping together with domestic workers } \\
\hline Never & 1.0 & 1.0 & 1.0 & 1.0 & 1.0 & 1.0 \\
\hline Sometimes/frequently & $2.6(0.9$ to 7.1$)$ & $1.5(0.5$ to 4.6$)$ & $1.1(0.5$ to 2.6$)$ & $1.1(0.5$ to 2.7$)$ & $1.0(0.7$ to 1.5$)$ & $1.2(0.6$ to 2.4$)$ \\
\hline \multicolumn{7}{|l|}{ Smoking and alcohol intake } \\
\hline \multicolumn{7}{|l|}{ Smoking } \\
\hline Never smoke & 1.0 & 1.0 & 1.0 & 1.0 & 1.0 & 1.0 \\
\hline Smoker/ex-smoker & 1.5 (0.8 to 2.8$)$ & $1.2(0.5$ to 2.5$)$ & $1.1(0.8$ to 1.7$)$ & $1.3(0.8$ to 2.1$)$ & 1.2 (0.9 to 1.7$)$ & $1.3(0.9$ to 1.9$)$ \\
\hline \multicolumn{7}{|l|}{ Alcohol intake } \\
\hline Never drank & 1.0 & 1.0 & 1.0 & 1.0 & 1.0 & 1.0 \\
\hline Drinker/ex- drinker & $3.8(2.0 \text { to } 7.1)^{\star \star \star}$ & $3.4(1.5 \text { to } 7.2)^{\star \star}$ & 0.9 (0.6 to 1.4$)$ & $0.8(0.5$ to 1.4$)$ & 0.9 (0.6 to 1.4$)$ & 1.4 (0.9 to 2.2$)$ \\
\hline
\end{tabular}

Table 5 Crude and adjusted lifetime sexual behaviours associated with practising unsafe sex by residential status and among all workers together ( $\mathrm{N}=460)$

\begin{tabular}{|c|c|c|c|c|c|c|}
\hline & \multicolumn{4}{|l|}{ Residential status } & \multirow{2}{*}{\multicolumn{2}{|c|}{ All }} \\
\hline & \multicolumn{2}{|l|}{ Domestic } & \multicolumn{2}{|l|}{ Foreigner } & & \\
\hline & OR (95\% Cl) & aOR $(95 \% \mathrm{Cl})$ & OR (95\% Cl) & aOR (95\% Cl) & OR (95\% Cl) & aOR† $(95 \% \mathrm{Cl})$ \\
\hline \multicolumn{7}{|l|}{ Sexual behaviour } \\
\hline \multicolumn{7}{|l|}{ Lifetime sexual debut } \\
\hline Before joining QIZ & 1.0 & 1.0 & 1.0 & 1.0 & 1.0 & 1.0 \\
\hline After joining QIZ & $2.0(1.1 \text { to } 3.8)^{*}$ & $2.2(1.1 \text { to } 4.4)^{\star}$ & $2.2(1.4 \text { to } 3.5)^{\star \star}$ & $2.4(1.4 \text { to } 4.1)^{\star \star}$ & $2.1(1.4 \text { to } 3.1)^{\star \star *}$ & $2.4(1.6 \text { to } 3.6)^{\star \star \star}$ \\
\hline \multicolumn{7}{|l|}{ Age at first sex } \\
\hline$\geq 25$ & 1.0 & 1.0 & 1.0 & 1.0 & 1.0 & 1.0 \\
\hline$\leq 24$ & $18.6(7.6 \text { to } 45.4)^{\star \star *}$ & $6.2(2.0 \text { to } 19.3)^{\star \star *}$ & $1.4(0.9$ to 2.3$)$ & $1.0(0.6$ to 1.8$)$ & $3.1(2.1 \text { to } 4.6)^{\star \star \star}$ & $1.8(1.1 \text { to } 2.8)^{\star}$ \\
\hline
\end{tabular}

aOR, adjusted odds ratio for sociodemographics, STIs-related knowledge and smoking and alcohol intake.

${ }^{*} p \leq 0.05 ;{ }^{* *} p<0.01 ;{ }^{* * *} p<0.001$.

†Adjusted also for residential status.

QIZ, Qualified Industrial Zone; STIs, sexually transmitted infections. 
The high rate of unsafe sex detected among sexually active domestic male workers was $25 \%$ higher than that among domestic workers reported in 2008 in other QIZs $(33 \%)$ and $98 \%$ higher than that among domestic workers in small business $(21 \%)$ in Jordan. ${ }^{23}$ The obtained prevalence was also higher than the rate of sex with commercial sex workers among male injection drug users in Egypt. ${ }^{27}$ The Jordanian population is in general culturally and socially restrained in its attitudes towards free sexuality, and casual sexual intercourse is less likely to occur between Jordanian males and females. ${ }^{20} 28$ Owing to the lack of epidemiological studies examining rates of unsafe sex among other groups in Jordan, the obtained rate of unsafe sex among this particular group of workers in the sampled QIZ may not be generalised to other populations in Jordan.

Migrants are documented as a high-risk group for unsafe sexual behaviour. ${ }^{12-5}$ This study further revealed that the high rate of unsafe sex among migrant workers is in line with that reported among male migrants in India $^{29}$ in Bangladesh $^{1}$ and among adults in Sri Lanka. ${ }^{30}$ This result confirmed findings of previous reports documenting that migrant workers are one of the most at-risk groups for unsafe sexual behaviour. ${ }^{2}{ }^{3}$

In the present study, domestic workers who had lifetime sexual debut after joining the QIZ or who frequently/sometimes did shopping with foreign workers were more likely to engage in unsafe sex. The exposure to sexually liberal cultures significantly influences the acquisition of risky sexual behaviours and STIs. ${ }^{31}{ }^{32}$ This study assumes that working in multinational workplaces facilitates exposure to and socialisation with workers from different backgrounds, which in turn facilitates engagement in unsafe behaviours. Although this is a new finding, the significance of socialisation among people from different social backgrounds should be further studied in relation to behaviour changes.

Risky health behaviours, such as smoking, alcohol drinking and early sexual debut, were common in this study. More than half of the domestic workers and nearly half of the foreign workers were current tobacco smokers. The high rate of tobacco smoking among domestic workers is higher than that recently revealed among adults aged $18+$ years in Jordan. ${ }^{33}$ Islam typically prohibits drinking alcoholic beverages, and alcohol drinking is socially unacceptable in the society under consideration, where it generates social stigmatisation. However, in this study, nearly $10 \%$ of the domestic Muslim workers were current alcohol drinkers. This figure reflects the observed rise in the number of alcohol drinkers in Jordan according to the Jordanian Anti-Narcotics Department. ${ }^{34}$ Furthermore, early sexual debut is associated with lack of condom usage and having multiple sexual partners, ${ }^{35}$ domestic and foreign workers in this study who had their first sex at the age of $\leq 24$ years were more likely to practise unsafe sex. Effective programmes on tobacco smoking, alcohol drinking and on early sexual practices in multinational workplaces are needed.
The overall percentage of sexually active workers who never used condoms in the previous 12 months was high. Condoms are shown to be effective in protecting against STIs. ${ }^{32}$ The noticed low condom usage among domestic workers can be attributed to their inadequate knowledge about the importance of condoms in preventing STIs. A bivariate model showed that domestic workers who had never heard of condoms or reported that 'condoms cannot protect against STIs' were more likely to practise unsafe sex.

Nearly one-third of all workers reported that they had never heard the term 'sexually transmitted infections' and nearly one quintile of them had HIV/AIDS knowledge scores ranging from 0 to 7 . Furthermore, four quintiles of workers reported having never attended any workshops on STIs/AIDS. Sexual education has been found to play an essential role in preventing unsafe sex and dissemination of STIs. ${ }^{36} 37$ These findings demonstrate the importance of a call for action to tailor multilanguage STI and sexual education programmes to meet the specific needs of workers speaking different languages.

The findings of this study should be interpreted in the light of the following limitations. The behavioural data were collected from a cross-sectional survey, and the findings are based on self-reports; therefore, the collected data may be subject to underestimation and social desirability bias. Embarrassment about disclosing personal information related to sexual behaviour is understandable. The true prevalence of unsafe behaviour could be even higher than that found here.

\section{CONCLUSIONS}

A significant proportion of workers were engaged in unsafe sexual behaviours. A high rate of unsafe sex was found among workers with lifetime sexual debut after joining the QIZ and among workers socialising with other foreign workers. Not only foreigners, but also domestic workers working with foreign workers in multinational workplaces, have a high risk of unsafe sex. Lower rates of STI-related knowledge and condom usage were also found among multinational workers in the QIZ. Multinational workers in the QIZs should be prioritised for public health interventions in preventing unsafe sex and health-related risky behaviours.

Acknowledgements The authors express their grateful appreciation to the study subjects for their voluntary participation and to all the selected factories that gave us their time and space. The authors thank are extended to the Head of the Department of STIs at Irbid Health Directorate, Dr Nayef Al-Jarrah, for his role in communicating with the factories and providing technical assistance.

Contributors RA and KN conceptualised and designed the study. RA made arrangements with the stakeholders, collected and analysed the data, and drafted and wrote the final manuscript. RA, KN, SK, MK and AM made substantial contributions to the analysis and interpretation of data and revised the manuscript critically for important intellectual content and gave final approval of the version to be published.

Funding This study was supported by a Grant-in-aid for Scientific Research from the Japan Society for the Promotion of Science (JSPS), Grant Number 24390164. 
Competing interests None declared.

Patient consent Obtained.

Ethics approval Jordan Ministry of Health.

Provenance and peer review Not commissioned; externally peer reviewed.

Data sharing statement No additional data are available.

Open Access This is an Open Access article distributed in accordance with the Creative Commons Attribution Non Commercial (CC BY-NC 4.0) license, which permits others to distribute, remix, adapt, build upon this work noncommercially, and license their derivative works on different terms, provided the original work is properly cited and the use is non-commercial. See: http:// creativecommons.org/licenses/by-nc/4.0/

\section{REFERENCES}

1. Roy T, Anderson C, Evans C, et al. Sexual risk behavior of rural-tourban migrant taxi drivers in Dhaka, Bangladesh: a cross-sectional behavioral survey. Public Health 2010;124:648-58.

2. Hesketh T, Li L, Ye X, et al. HIV and syphilis in migrant workers in eastern China. Sex Transm Infect 2006;82:11-14.

3. Wang B, Li X, Stanton B, et al. Gender differences in HIV-related perceptions, sexual risk behaviors, and history of sexually transmitted diseases among Chinese migrants visiting public sexually transmitted disease clinics. AIDS Patient Care STDS 2007;21:57-68.

4. Pandey A, Benara SK, Roy N, et al. Risk behaviour, sexually transmitted infections and HIV among long-distance truck drivers: a cross-sectional survey along national highways in India. AIDS 2008;22(Suppl 5):S81-90.

5. Saggurti N, Nair S, Malviya A, et al. Male migration/mobility and HIV among married couples: cross-sectional analysis of nationally representative data from India. AIDS Behav 2012;16:1649-58.

6. Adam MB, McGuire JK, Walsh M, et al. Acculturation as a predictor of the onset of sexual intercourse among Hispanic and White teens. Arch Pediatr Adolesc Med 2005;159:261-5.

7. Abraído-Lanza AF, Chao MT, Flórez KR. Do healthy behaviors decline with greater acculturation? Implications for the Latino mortality paradox. Soc Sci Med 2005;61:1243-55.

8. De P, Cox J, Boivin JF, et al. The importance of social networks in their association to drug equipment sharing among injection drug users: a review. Addiction 2007;102:1730-9.

9. Latkin CA, Kuramoto SJ, Davey-Rothwell MA, et al. Social norms, social networks, and HIV risk behavior among injection drug users. AIDS Behav 2010;14:1159-68.

10. United Nations, World Population Prospects. http://esa.un.org/unpd/ wpp/unpp/panel_indicators.htm (accessed 17 Nov 2014).

11. The World Bank, International migrant stock, total. http://data worldbank.org/indicator/SM.POP.TOTL (accessed 10 Oct 2014).

12. United Nations Relief and Works Agency (UNRWA). http://www. unrwa.org/syria-crisis\#zoom $=5 \&$ lat $=34.05266 \& l o n=33.574228$ layers $=0$ TOB00 (accessed 5 Sep 2014)

13. The United Nation Refugee Agency (UNHCR). http://www.unhcr.org/ pages/49e486566.html (accessed 12 Sep 2014)

14. The United Nation Refugee Agency (UNHCR), stories from Syrian refugees, facts and figures about Syrian refugees. http://www.unhcr. org/pages/49e486566.html (accessed 18 Sep 2014)

15. Ministry of Labour of Jordan, qualified industrial zones, monthly report (Report in Arabic). http://www.mol.gov.jo/Portals/0/qiz/qiz52011.pdf (accessed 18 Sep 2013).

16. Gharaybeh K. General socio-demographic characteristics of the Jordanian society: a study in social geography. Res Humanit Soc Sci 2014;4:1-10.
17. Department of Statistics [Jordan] and ICF International. Jordan population and family health survey 2012. Calverton, Maryland, USA: Department of Statistics and ICF International, 2013.

18. Jordan Invest Trust P.L.C. http://jordinvest.com.jo/uploads/ documents/jtel.pdf (accessed 16 Nov 2014)

19. Central Intelligence Agency. The World Factbook: Jordan. 2013. https://www.cia.gov/library/publications/the-world-factbook/geos/jo. html (accessed 10 Nov 2014).

20. Turner T, Fox N, Kiser J. Uniting spirituality and sexual counseling: semitic traditions. Fam J 2007:15:294-7.

21. Mahafzah AM, Al-Ramahi MQ, Asa'd AM, et al. Prevalence of sexually transmitted infections among sexually active Jordanian females. Sex Transm Dis 2008;35:607-10.

22. Ministry of health of Jordan. Epidemiological situation. http://www. moh.gov.jo/EN/Pages/mainind.aspx?ind=http\%3a//apps.moh.gov.jo/ reports/headermain.jsp?firstjsp=epimedsituationmenu\&lang parameter=english (accessed 14 Nov 2014).

23. USAID and Family Health International. Knowledge, Attitudes, and Practices Survey of Workers in Qualified Industrial Zones and Small Businesses in Jordan. http://pdf.usaid.gov/pdf_docs/Pnadm793.pdf (accessed 26 Oct 2014).

24. Pan X, Zhu Y, Wang Q, et al. Prevalence of HIV, syphilis, HCV and their high risk behaviors among migrant workers in Eastern China. PLOS ONE 2013;8:e57258

25. The Labour Tripartite Commission Order of 31/12/2011, setting the monthly minimum wage. Al Jarida El Rasmiyah, 2011-12-31, No. 5134, P. 5616-P. 5617. Legislation on-line in Arabic, Prime Ministry, The Hashemite Kingdom of Jordan, Jordan. http://www.lo. org/dyn/natlex/docs/ELECTRONIC/90853/105007/F-1293453209/ 5134-2.pdf (PDF in Arabic) (accessed 15 Apr 2015)

26. Van Griensven F, Supawitkul S, Kilmarx PH, et al. Rapid assessment of sexual behavior, drug use, human immunodeficiency virus, and sexually transmitted diseases in northern Thai youth using audio-computer-assisted self-interviewing and noninvasive specimen collection. Pediatrics 2001;108:E13.

27. Soliman C, Rahman IA, Shawky S, et al. HIV prevalence and risk behaviors of male injection drug users in Cairo, Egypt. AIDS 2010;24(Suppl 2):S33-8.

28. Awwad ZM, Al-Amarat AA, Shehabi AA. Prevalence of genital chlamydial infection in symptomatic and asymptomatic Jordanian patients. Int J Infect Dis 2003;7:206-9.

29. Dave SS, Copas A, Richens J, et al. HIV and STI prevalence and determinants among male migrant workers in India. PLOS ONE 2012; 7:e43576.

30. Perera B, Reece M. Sexual behavior of young adults in Sri Lanka: implications for HIV prevention. AIDS Care 2006;18:497-500.

31. Kepka D, Coronado G, Rodriguez $\mathrm{H}$, et al. Acculturation and HPV infection among Latinas in the United States. Prev Med 2010;51:182-4.

32. Martin ET, Krantz E, Gottlieb SL, et al. Pooled analysis of the effect of condoms in preventing HSV-2 acquisition. Arch Intern Med 2009;169:1233-40.

33. Jaghbir M, Shareif S, Ahram M. Quitting smoking and utilization of smoking cessation services in Jordan: a population-based survey. East Mediterr Health J 2014;20:538-46.

34. Al-Omari $\mathrm{H}$, Hamed $\mathrm{R}, \mathrm{Abu}$ Tariah $\mathrm{H}$. The role of religion in the recovery from alcohol and substance abuse among Jordanian adults. J Relig Health. Published Online First: 1 May 2014

35. Li J, Li S, Yan H, et al. Early sex initiation and subsequent unsafe sexual behaviors and sex-related risks among female undergraduates in Wuhan, China. Asia Pac J Public Health 2015; 27(2 Suppl):21S-9S

36. Grose RG, Grabe S, Kohfeldt D. Sexual education, gender ideology, and youth sexual empowerment. J Sex Res 2014;51:742-53.

37. Palihawadana TS, Dissanayake DMAB, Harshanie A, et al. Chlamydia trachomatis infection in an infertile population: a cross-sectional study. Sri Lanka J Obs Gyn 2010;32:85-8. 